\title{
PUBLIC HEALTH PERSPECTIVES DUE TO CLIMATE CHANGE IN BANGLADESH
}

Kabir $R^{1}$, Yasir Arafat S.M. ${ }^{2}$

\section{Affiliation}

1. Department of Medical Science and Public Health, Anglia Ruskin University, UK

2. Department of Psychiatry, BSMMU, Dhaka, Bangladesh

\section{A R TI CLE INFO}

\section{Article History}

Received :

Accepted

Published : 31 December, 2017

(c) Authors retain copyright and grant the journal right of first publication with the work simultaneously licensed under Creative Commons Attribution License CC - BY 4.0 that allows others to share the work with an acknowledgment of the work's authorship and initial publication in this journal.

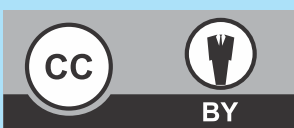

VP 1

\section{DOI: $\underline{\text { http://dx.doi.org/10.3126/bjhs.v2i3.18956 }}$}

\author{
* Corresponding Author \\ Yasir Arafat SM \\ Department of Psychiatry, BSMMU, Dhaka, Bangladesh \\ Email:arafatdmc62@gmail.com
}

\section{Citation}

Kabir R, Yasir Arafat SM. Public Health Perspectives Due To Climate Change In Bangladesh. BJHS 2017;2(3)4 : 316-317
In recent times, the print and electronic media were very busy in covering the news flooding in Bangladesh, Nepal and India, Hurricane Harvey and Irma in US. The frequency of extreme weather events around the world is increasing due to global climate change. Bangladesh being close to the Bay of Bengal is very vulnerable to climate change. Bangladesh positioned in the monsoon belt with the Himalayas in the north of it. Snow melting in the Himalayas due to recent global warming and heavy rainfall increases the chances of flooding in Bangladesh. Every year this country faces severe natural calamities that bring unprecedented sorrows and miseries for the people of Bangladesh. The economic status of Bangladesh is on rise but over population and extreme weather events are posing as great threats to its economic and infrastructural development. Research projects that, Bangladesh will be one of the worst victims of climate change though it has no role of causing it ${ }^{1}$. An extensive number of people in Bangladesh are still living below the poverty line and natural disasters generally worsen the poverty-stricken people who are in and around the poverty threshold. These people who live under the poverty line have less access to proper sanitation facilities and there is greater chance that climate change will have a bigger impact on diarrhoeal diseases in Bangladesh ${ }^{2}$. The actual health problems that are due to climate change is influenced by local environmental conditions, socioeconomic status of the population and behavioural adaptations of the communit ${ }^{3}$.

A number of studies indicated that climate change has affecting general health of the population in Bangladesh ${ }^{1}$. Climate change increases the incidences of water borne and air borne diseases and changes in the climatic condition is suitable for bacteria, parasites and disease vectors to breed very rapidly ${ }^{4}$. The magnitude of malaria, dengue, childhood diarrhoea and pneumonia is very high among the affect communities $^{3}$ in Bangladesh. Climate change is also responsible for severe health problems like dehydration, malnutrition and heat related morbidity among the children and elderly population ${ }^{4}$. In Bangladesh, so far number of health problems like colds, coughs, fevers, dysentery, headaches, skin diseases, burning sensations, conjunctivitis, jaundice, Hepatitis-B, skin burns/blistering, asthma, typhoid, pox, weight loss, rheumatism/aching, pneumonia are associated with extreme weather events ${ }^{4}$. With increasing 
temperature, there will be heat stress or hypothermia among the people in the urban areas and it has been found that rise of temperature also has a link with rise of renal problem and mental disaorders ${ }^{2}$. Extreme weather events such as droughts, floods and cyclones can cause contamination of drinking water and this causes of shortage of drinking water in the affected communities and rapidly spread infections causing an outbreak $^{5}$. Extreme climatic conditions not affecting human health directly, there is decreased food production and it is aggravating the cases of malnutrition, affecting the income sources of the households and education of children ${ }^{6}$. Climate change also made so many people homeless and displaced in the coastal regions of Bangladesh and health care expenditure has increased after the extreme weather events ${ }^{3}$.

Global warming will cause more rapid replication of dengue viruses in Bangladesh ${ }^{7}$ and Chikungunya virus in also an emerging infectious disease in Bangladesh. Moreover, the prevention strategies are inadequate to reduce the risk among general population ${ }^{8}$. It is obvious that from current evidences that climate change poses a great threat to public health in Bangladesh considering the poorly developed support system and health infrastructure the country ${ }^{5}$. Policy makers should take measure to reduce health care costs and improve services at remote areas both for public and private services ${ }^{9}$ and different stakeholders like government and nongovernment should work collaboratively to tackle climate induced health problems among the communities. Many developing countries facing the threat of climate change, Bangladesh is already bearing the burden of it. Due to sea level rise salinity has intruded deeper into the country, recent devastating cyclones killed thousands of people and damaged to crops and assets, summers are becoming extremely hot and rainfall is becoming erratic, exotic diseases are spreading and climate change related stresses are causing thousands of additional deaths in Bangladesh every year. Bangladesh now have no option left but to brace herself for the adverse impacts of climate change. There is potential risk of climate change on human health in Bangladesh. Future research is required to establish this, health systems need more logistical and operational support to deal with climate induced health problems and community adaptation measures should be encouraged to reduce the severity of health problems.

\section{CONFLICT OF INTEREST}

The authors declare no conflict of interest.

\section{REFERENCES}

1. Kabir, R. and Khan, H.T. A. Climate change induced natural disasters impact on the health of the coastal people in Bangladesh. International Journal of Perceptions in Public Health, 2016;1(1):9-12.

2. Shahid, S. Probable impacts of climate change on public health in Bangladesh. Asia Pacific Journal of Public Health, 2010;22(3):310319.

3. Kabir, MI, Rahman, MB, Smith, W, Lusha, MAF, and Milton, AH. Climate change and health in Bangladesh: a baseline cross-sectional survey. Global health action.2016, 9(1), p.29609.

4. Haque MA, Budi A, Malik AA, Yamamoto SS, Louis VR, Sauerborn R. Health coping strategies of the people vulnerable to climate change in a resource-poor rural setting in Bangladesh. BMC Public Health. 2013;10;13(1):565.

5. World Bank. Climate change and health impacts: how vulnerable is Bangladesh and what needs to be done? Disaster Risk and Climate Change Unit, Sustainable Development Department, South Asia Region, 2014.
6. Kabir, R, Khan, H.T.A, Ball, E and Caldwell,K. Climate change and public health situations in the coastal areas of Bangladesh. International Journal of Social Science Studies, 2(3):109-116

7. Rahman A. Climate change and its impact on health in Bangladesh. In Regional Health Forum, 2008; 12(1):16-26.

8. Khatun S, Chakraborty A, Rahman M, Banu NN, Rahman MM, Hasan SM, Luby SP, Gurley ES. An outbreak of chikungunya in rural Bangladesh, 2011. PLoS neglected tropical diseases. 2015 10;9(7):e0003907.

9. Kabir, R \& Khan, H.T. A. Study on the health status of coastal people in Bangladesh after cyclone Sidr and Aila. European Scientific Journal,2017;13(15):10-21. 